For example, if a region of the brain is damaged, causing loss of certain functions, it is hard to tell whether these functions are represented in that specific area or whether the loss is caused by a disconnection of two areas whose interaction is required.

Very recently, brain-activity measurements have shed new light on language representation and learning in the healthy human brain. For example, by using a cortical brain response termed 'mismatch negativity', it is possible to study the long-term memory representations of speech sounds of an individual's native language. Subsequent studies have shown how these native-language representations develop in early childhood, and what plastic changes accompany the development of the new phonetic categories of a foreign language learned in adulthood. Since this is a fairly recent development in neurolinguistics, however, it is understandable that it is not covered in the book.

In conclusion, this interesting and very clearly written book provides a good introduction to the way in which multiple languages are represented in the brain based on what we know from brain-lesioned patients. After reading it, an enthusiastic neurolinguist or neuroscientist will look forward to the next volume, elucidating bilingualism from studies on the healthy human brain. $\square$ Risto Näätänen and Teija Kujala are at the Cognitive Brain Research Unit, Department of Psychology, PO Box 13, FIN-00014 University of Helsinki, Helsinki, Finland.

\section{Hallo capitalism, goodbye science}

\section{What Have We Learned about Science and Technology from the Russian Experience?}

by Loren R. Graham

Stanford University Press: 1998. 165 pp.

$\$ 14.95, £ 10.95$ ( $p b k$ ).

\section{Zhores A.Medvedev}

The early history of Soviet science was very tragic indeed. Thousands of scientists, both prominent and unknown, perished in the Gulag. Biologists were forced to follow the pseudoscientific theories of Lysenko and other charlatans. The best aeroplane designers had their engineering facilities attached to special prisons. Promotion to a senior position, even in universities or institutes engaged in fundamental research, required membership of the Communist Party. Foreign travel was impossible. In libraries, even Nature fell prey to the censor's scissors.

But despite all this, Soviet science behind the Iron Curtain did reasonably well. It gave Stalin atomic and thermonuclear bombs much more quickly than did the scientists working for the democratic governments of
Britain and France, and it made antibiotics available for free health care throughout the USSR. The volume of research, basic and applied, and the number of research institutes grew rapidly. With Sputnik a few years later Soviet science and technology started to receive great respect and attention. In 1960, when Loren R. Graham arrived at Moscow University to study the history of the Academy of Sciences of the USSR, the Soviet Union had more researchers and engineers than the United States, and there were many areas of excellence, innovation and technological breakthroughs. Soviet scientists were world leaders in several fields.

In later years, Soviet science and technology continued to grow rapidly, but its efficiency did not keep pace with its size. This was mainly due to poor cooperation among the main sectors of research activity (universities, academies and ministries) and the vast military complex that consumed so much of the research and development budget.

Why, in new and democratic Russia, were science and technology treated so differently and deprived of financial support? Why did the transition from totalitarianism to democracy, from socialism to capitalism, harm the research capabilities much more than the infrastructure of science itself?

Graham, a leading historian of Soviet science and technology, tries his best to avoid political analysis and to link the developments in science with the general reform process. In his earlier books, Graham, like many other American historians, did not predict that science would collapse together with communism. It was believed that the development of science and technology in communist countries had a 'westernizing' influence, and that "science and technology have helped to make Soviet society more like the rest of the world, eroding the revolutionary and exceptional ethos in which the USSR was born" (Science and the Soviet Social Order, Harvard University Press, 1990). Among Soviet scientists, there was a general expectation that being free to exchange information, choose their collaborators and travel would aid their research, increase productivity and promote their integration into the world of science.

There was nothing wrong with this theory, or its expectations. The failure was with the transition itself. It was initiated as a stepby-step process by Mikhail Gorbachev, but was accelerated into the collapse of the USSR by Boris Yeltsin. As a result, a much smaller and poorer Russia was left with a research infrastructure that was too large and expensive, and most of the problems of 'big science' and military-industrial development became entirely irrelevant. With the largest external debt in the world, not only science and technology, but all state-dependent services health, education, security and police have been forced onto a survival regime with

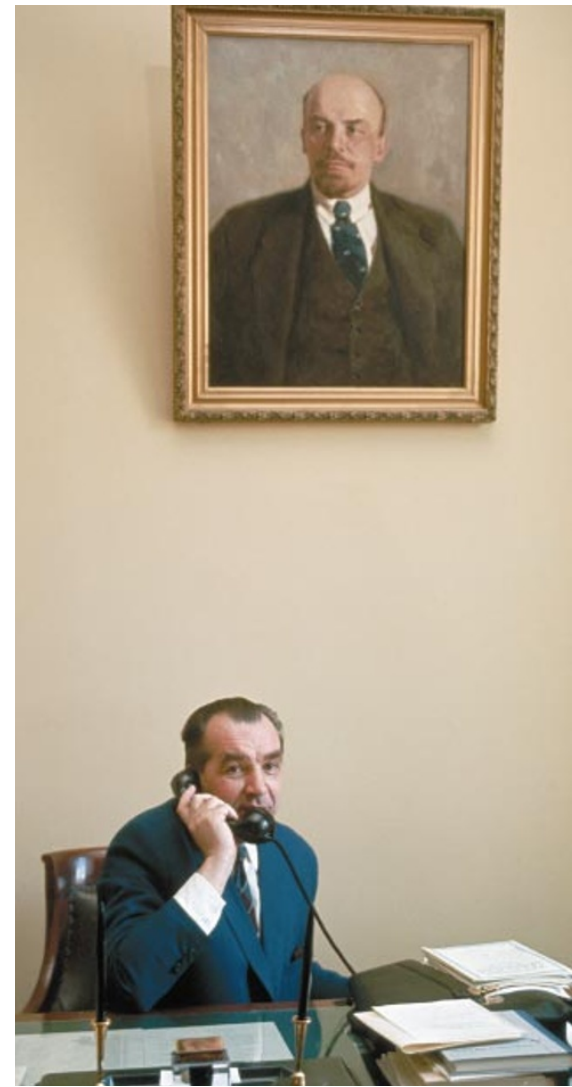

Picture of health: Nikolai Blokhin, president of the USSR Academy of Medical Sciences, in 1964.

a subsistence level of government support. The current Russian budget is approximately the same as Denmark's.

Graham describes how some famous Russian research institutes have responded to poverty. They have usually reduced research expenses while trying hard to avoid redundancies. When resources get too low, they reduce salaries, often to levels of destitution, but try to keep staff, even if scientists cannot do much, or anything. They let parts of their - fortunately large - buildings to foreign companies or commercial firms and transform their fenced territories into paid parking lots for the expensive cars of the new elite.

This is not only a survival technique, but humanitarian as well. There are no redundancy payments, early retirement schemes or even unemployment benefits in Russia for scientists who lose their jobs. Some other state services, such as health, do the same. People continue to work even when they are not paid for months. They know that if they stop the situation will get worse, not better. But if we really want to take something from the Russian experience, it is that Russia is doing much better than the other republics of the former Soviet Union. Scientists in the Ukraine have started to wonder, half-jokingly, if their government will introduce entrance fees for their institutes.

Zhores A. Medvedev is at the National

Institute for Medical Research, The Ridgeway,

London NW7 1AA, UK. 